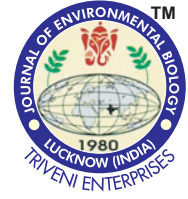

\title{
The inhibiting effects of scots pine (Pinus sylvestris) on germination ability and growth of some culture ryegrass species
}

\section{Authors Info}

M. Aklıbaşında', E.A. Külekçi', M. Demir ${ }^{2 *}$ and Y. Bulut ${ }^{2}$

'Department of Landscape Architecture, Nevsehir Haci Bektas Veli University, Nevsehir-50300, Turkey

${ }^{2}$ Department of Landscape Architecture, Ataturk University, Erzurum-25240, Turkey

*Corresponding Author Email : metin@atauni.edu.tr

Key words

Allelopathy,

Grass plant,

Root,

Scots Pine

Publication Info

Paper received : 23.05.2016

Revised received : 29.05.2017

Accepted : 28.06.2017

\section{Abstract}

Aim : Allelochemicals present in some plants exert inhibitory effects on growth and development of other plants. This study was carried out due to the observation of weak development in the ryegrass under Scots Pine to explore whether allelochemicals contained by the leaves of Scots Pine (Pinus sylvestris sp.) plant had an inhibitory effect on germination ability and development of Lolium multiflorum 'Casamba', Agrostis tenuis 'Highland' and Festuca arundinacea 'Apache' culture forms among ryegrass plants.

Methodology : Extracts collected from dried Scots pine (Pinus sylvestris sp.) leaves were applied to specified grass seeds at different test concentrations $\left(10,20,30,40\right.$ and $\left.50 \mathrm{~g} \mathrm{l}^{-1}\right)$. Control group was incubated with distilled water, while treatment groups were incubated with $4 \mathrm{ml}$ of prepared extracts.

Results : Findings indicated that these extracts had inhibitory effects on germination and growth in grass plants depending on the seed type and applied concentrations. Among these analyzed three species, the highest allelopathic (inhibitory) effect dependent to concentrations was observed in $A$. tenuis, while the lowest allelopathic effect was observed in L. multiflorum species.

Interpretation : Allopathic effect should be considered when ryegrass is planted under the pine trees to preventeconomiclosses.

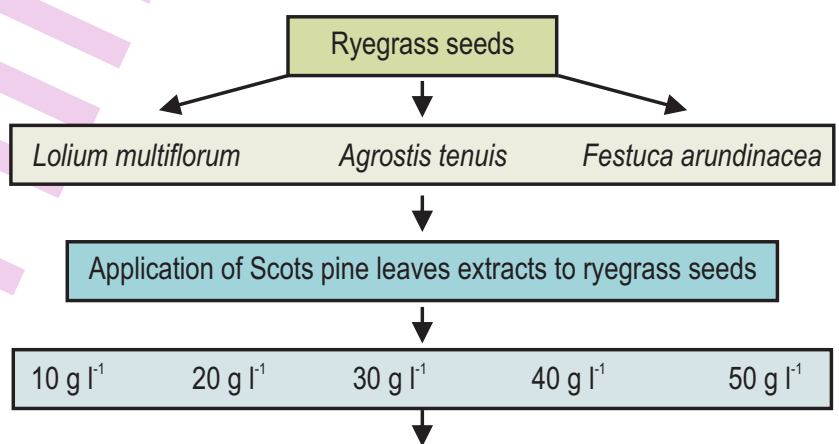

Compared to "Control Group"

*Seed germination * *Root length *Root number *Shoot length *Shoot number

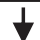

Inhibitory effects of Scots pine leave extract on germination and growth in ryegrass 


\section{Introduction}

Plants having unknown defense mechanisms, can protect themselves from insecticides, fungicides and thousands of secretions of other plants (Çamurköylü and Demirkan 1993). Toxic substances secreted by some plants can inhibit growth and development of other plants. In addition to direct or indirect harmful effects on plants, allelopathic chemicals might have beneficial effects as well (Rice, 1984). Allelopathic chemicals are generally secreted by the leaves of the plant; they can also be secreted from the flowers, shoots, roots of living plants or from plant residues after harvesting (Putnam and DeFrank, 1983; Jefferson and Pennacchio, 2003; Roshchina, 2009).

Generally ligneous plants have allelopathic effects on herbaceous plants. Earlier studies demonstrated that these allelopathic effects were caused by the chemicals secreted from some ligneous plants (tree or bushes) (Chaves and Escudero 1997; Kocaçalışkan and Terzi 2001; Boz et al., 2003; Djurdjvic et al., 2005; Ercişli et al., 2005; Bulut and Demir 2007; Roshchina et al., 2011). Similarly, it was observed that ryegrass under Scots pine trees in Erzurum (eastern Turkey) had a weak development. The study examined allelopathic effects of Scots pine (Pinus sylvestris sp.) among the ligneous plants of the region in Erzurum, which is one of the largest cities of the region, on some commonly used cool climate ryegrass species. The findings of the study are important for the identification of species and mixtures which will be selected while creating ryegrass areas under Scots pine trees.

\section{Materials and Methods}

In Erzurum province (eastern Turkey), cool climate ryegrass, which can develop in continental climate regions, are preferred for creating ryegrass areas. Therefore, the material of the study consisted of Lolium multiflorum 'Casamba', Agrostis tenuis 'Highland' and Festuca arundinacea 'Apache' seeds among cool climate ryegrass varieties and Scots pine leaves collected from Ataturk University forest in September.

The study was carried out under controlled laboratory conditions. Collected Scots pine leaves were washed with distilled water and oven-dried at $45{ }^{\circ} \mathrm{C}$ for $72 \mathrm{hrs}$. Dried leaves were ground and mixtures were prepared with distilled water at $10,20,30,40$ and $50 \mathrm{~g} \mathrm{I}^{-1}$ concentrations. These mixtures were kept at $27 \pm 1^{\circ} \mathrm{C}$ for $24 \mathrm{hrs}$, filtered with Whatman No.2 filter paper and pine leaves extracts were obtained. The test was performed with three replicates. Whatman No.1 filter paper and 30 seeds were placed in $90 \times 12 \mathrm{~mm}$ plastic petri dishes for each replicate. Petri dishes were kept at controlled laboratory conditions (60$65 \%$ relative humidity, and at $25^{\circ} \mathrm{C}$ temperature providing $16 \mathrm{hrs}$ light and 8 hrs dark period). Control group was incubated with distilled water, while treatment groups incubated with $4 \mathrm{ml}$ of prepared extracts $\left(10,20,30,40\right.$ and50 $\left.\mathrm{gl}^{-1}\right)$.
Number of germinated seeds in each Petri dish was recorded on daily basis. As described by Agboola (1998) one mm root was taken as a basis as germination criteria. Germination percentage, root length $(\mathrm{cm})$ and root number, shoot length $(\mathrm{cm})$ and shoot number values were obtained at the end of 30-day-test. Arcsin transformation was used to evaluate germination percentages. Study data was subjected to analysis of variance and means of main variation sources which were found to be statistically significant were compared with Duncan Multiple Comparison Test.

\section{Results and Discussion}

Results indicated the concentration dependent allelopathic effect of Scots pine leaves on germination and growth (root length, root number, shoot length, shoot number) of $L$. multiflorum, $A$. tenuis and $F$. arundinacea. As the concentration density increased, the means of all these parameters decreased. The statistical significance of decrease was expressed in the tables with lower-case letters in the same line. According to this, the means in the same line, not sharing a common letter, were significantly different at $P<0.01$ error level.

In L. multiflorum, allelopathic effect of pine extracts was not found to be statistically significant until $50 \mathrm{~g} \mathrm{l}^{-1}(P<0.01)$ in terms of germination percentage; however it was observed that there was a concentration wise decrease. As for $F$. arundinacea, there was no statistically significant difference up to $30 \mathrm{~g} \mathrm{I}^{-1}$; however there was a statistically significant difference between the control, 40 and $50 \mathrm{~g} \mathrm{I}^{-1}(\mathrm{P}<0.01)$. On the other hand in $A$. tenuis, concentrations higher than $20 \mathrm{~g} \mathrm{I}^{-1}$ revealed significant inhibitory effects on germination percent as compared to control values $(P<0.01)$. So that germination completely stopped at $50 \mathrm{gl}^{-}$ ${ }^{1}$ (Table 1).

Analysis of the changes in root length among growth parameters in the test showed that there was a decrease due to increased concentration. This allelopathic effect changed according to the species. In L. multiflorum, there was a statistically significant difference of means in comparison of control and higher concentration such as $50 \mathrm{gl}^{-1}(P<0.01)$. On the other hand in $A$. tenuis and $F$. arundinacea, root length significantly decreased at $20 \mathrm{gl}^{-1}(\mathrm{P}<0.01)$ extract (Table 2$)$.

In terms of root number, there was a statistically significant difference between the control and $50 \mathrm{~g} \mathrm{~L}^{-1}$ in $L$. multiflorum and $F$. arundinacea. On the other hand in $A$. tenuis, statistically significant allelopathic effect was determined at $40 \mathrm{~g} \mathrm{l}^{-1}$ concentration $(P<0.01)$ (Table 3).

When the varieties were analyzed separately, it was found that different treatments did not have a statistically significant allelopathic effect on shoot length of $L$. multiflorum, $F$. arundinacea and $A$. tenuis. However, as the dose of extract 
increased, means of these growth parameters decreased (Table 4). As germination completely stopped in $50 \mathrm{~g} \mathrm{I}^{-1}$ treatment, there was no development of shoots in A. tenuis.

As for the number of shoots among analyzed parameters, it was found that Scots pine extracts did not have a statistically significant allelopathic effect on L. multiflorum and $F$. arundinacea and it was observed that as extract concentration increased, the number of shoots decreased. On the other hand, in A. tenuis, there was a statistically significant inhibitory effect in densities higher than $30 \mathrm{gl}^{-1}(\mathrm{P}<0.01)$ (Table 5).

Allelochemicals are synthesized for secondary metabolisms of plants accumulate in certain organs of plants (Kobayashi, 2004). The most important allelochemicals in Scots pine plants are phenols, terpenes, resin acids which are particularly found in leaves in high concentrations (Nerg et al., 1994; Kainulainen and Holopainen 2001). Baradal and Yazdani (1988), Nerg et al. (1994), Muscolo and Sidari (2006) reported that allelochemicals contained by Pinus sylvestris varied

Table 1 : Effect of Scots pine leaf extracts on germination percent of seeds of three turf grass species

\begin{tabular}{|c|c|c|c|c|c|c|c|}
\hline Species & Control & $10 \mathrm{gl}^{-1}$ & $20 \mathrm{~g} \mathrm{l}^{-1}$ & $30 \mathrm{gl}^{-1}$ & $40 \mathrm{gl}^{-1}$ & $50 \mathrm{gl}^{-1}$ & LSD 0.1 \\
\hline Lolium multiflorum Casamba & $71.11^{\mathrm{a}}$ & $71.11^{\mathrm{a}}$ & $66.66^{\mathrm{a}}$ & $62.22^{\mathrm{ab}}$ & $54.44^{\mathrm{ab}}$ & $42.22^{b}$ & 11.950 \\
\hline Agrostis tenuis Highland & $66.00^{\mathrm{a}}$ & $36.66^{\mathrm{a}}$ & $33.33^{\mathrm{a}}$ & $8.88^{b}$ & $1.11^{\mathrm{b}}$ & $0^{\mathrm{b}}$ & 15.570 \\
\hline Festuca arundinacea Apache & $76.66^{\mathrm{a}}$ & $75.55^{\mathrm{a}}$ & $64.44^{\mathrm{ab}}$ & $57.77^{\mathrm{ab}}$ & $42.22^{\mathrm{bc}}$ & $27.77^{\circ}$ & 15.314 \\
\hline
\end{tabular}

Means in the same line with different lower-case letters are significantly different at $P<0.01$

Table 2 : Effect of Scots pine leaf extracts on total root length $(\mathrm{cm})$ of seedlings of three turf grass species

\begin{tabular}{|c|c|c|c|c|c|c|c|}
\hline Species & Control & $10 \mathrm{~g} \mathrm{I}^{-1}$ & $20 \mathrm{~g} \mathrm{I}^{-1}$ & $30 \mathrm{~g} \mathrm{I}^{-1}$ & $40 \mathrm{~g} \mathrm{I}^{-1}$ & $50 \mathrm{gl}^{-1}$ & LSD 0.1 \\
\hline Lolium multiflorum Casamba & $33.63^{\mathrm{a}}$ & $32.77^{\mathrm{a}}$ & $30.87^{a}$ & $29.87^{\text {a }}$ & $22.40^{\text {ab }}$ & $13.97^{b}$ & 13.751 \\
\hline Agrostis tenuis Highland & $4.63^{\mathrm{a}}$ & $4.48^{\mathrm{ab}}$ & $2.66^{\mathrm{bc}}$ & $0.93^{\text {cd }}$ & $0.27^{\mathrm{d}}$ & $0^{d}$ & 1.917 \\
\hline Festuca arundinacea Apache & $19.70^{\mathrm{a}}$ & $18.20^{\mathrm{a}}$ & $12.67^{b}$ & $9.93^{\mathrm{bc}}$ & $6.27^{\mathrm{cd}}$ & $1.93^{\mathrm{d}}$ & 5.512 \\
\hline
\end{tabular}

Means in the same line with different lower-case letters are significantly different at $P<0.01$

Table 3 : Effect of Scots pine leaf extracts on root number of three turf grass species

\begin{tabular}{|c|c|c|c|c|c|c|c|}
\hline Species & Control & $10 \mathrm{gl}^{-1}$ & $20 \mathrm{~g} \mathrm{l}^{-1}$ & $30 \mathrm{~g} \mathrm{l}^{-1}$ & $40 \mathrm{~g} \mathrm{l}^{-1}$ & $50 \mathrm{~g} \mathrm{l}^{-1}$ & LSD 0.1 \\
\hline Lolium multiflorum Casamba & $4.07^{\mathrm{a}}$ & $4.00^{\mathrm{a}}$ & $3.80^{\mathrm{ab}}$ & $3.57^{\mathrm{ab}}$ & $3.37^{\mathrm{ab}}$ & $3.00^{\mathrm{b}}$ & 0.852 \\
\hline Agrostis tenuis Highland & $3.70^{\mathrm{a}}$ & $2.23^{a b}$ & $2.13^{\mathrm{ab}}$ & $2.10^{a b}$ & $0.33^{b}$ & $0^{\mathrm{b}}$ & 2.486 \\
\hline Festuca arundinacea Apache & $3.57^{\mathrm{a}}$ & $3.17^{\mathrm{ab}}$ & $2.77^{\mathrm{ab}}$ & $2.73^{a b}$ & $2.63^{\mathrm{ab}}$ & $2.17^{\mathrm{b}}$ & 0.976 \\
\hline
\end{tabular}

Means in the same line with different lower-case letters are significantly different at $P<0.01$

Table 4 : Effect of Scots pine leaf extracts on total shoot length $(\mathrm{cm})$ of seedlings of three turf grass species

\begin{tabular}{|c|c|c|c|c|c|c|c|}
\hline Species & Control & $10 \mathrm{gl}^{-1}$ & $20 \mathrm{~g} \mathrm{l}^{-1}$ & $30 \mathrm{gl}^{-1}$ & $40 \mathrm{gl}^{-1}$ & $50 \mathrm{gl}^{-1}$ & LSD 0.1 \\
\hline Lolium multiflorum Casamba & $18.70^{\mathrm{a}}$ & $16.67^{\mathrm{a}}$ & $16.60^{a}$ & $15.87^{\mathrm{a}}$ & $15.67^{\mathrm{a}}$ & $15.20^{\mathrm{a}}$ & 5.156 \\
\hline Agrostis tenuis Highland & $3.73^{\mathrm{a}}$ & $2.73^{\mathrm{ab}}$ & $2.66^{\mathrm{ab}}$ & $1.77^{\mathrm{ab}}$ & $0.97^{\mathrm{ab}}$ & $0^{\mathrm{b}}$ & 2.615 \\
\hline Festuca arundinacea Apache & $9.63^{\mathrm{a}}$ & $9.63^{a}$ & $9.27^{\mathrm{a}}$ & $8.70^{\mathrm{a}}$ & $6.93^{\mathrm{a}}$ & $6.33^{\mathrm{a}}$ & 3.324 \\
\hline
\end{tabular}

Means in the same line with different lower-case letters are significantly different at $P<0.01$

Table 5: Effect of Scots pine leaf extracts on shoot number of three turf grass species

\begin{tabular}{|c|c|c|c|c|c|c|c|}
\hline Species & Control & $10 \mathrm{gl}^{-1}$ & $20 \mathrm{gl}^{-1}$ & $30 \mathrm{gl}^{-1}$ & $40 \mathrm{gl}^{-1}$ & $50 \mathrm{gl}^{-1}$ & LSD 0.1 \\
\hline Lolium multiflorum Casamba & $3.13^{\mathrm{a}}$ & $2.70^{\mathrm{a}}$ & $2.63^{\mathrm{a}}$ & $2.60^{\mathrm{a}}$ & $2.60^{\mathrm{a}}$ & $2.50^{\mathrm{a}}$ & 0.644 \\
\hline Agrostis tenuis Highland & $2.33^{\mathrm{a}}$ & $1.90^{\mathrm{a}}$ & $1.73^{\mathrm{a}}$ & $1.43^{\mathrm{ab}}$ & $0.33^{\mathrm{b}}$ & $0^{\mathrm{b}}$ & 1.109 \\
\hline Festuca arundinacea Apache & $2.37^{\mathrm{a}}$ & $2.03^{a}$ & $2.00^{\mathrm{a}}$ & $1.83^{\mathrm{a}}$ & $1.77^{\mathrm{a}}$ & $1.70^{\mathrm{a}}$ & 0.700 \\
\hline
\end{tabular}

Means in the same line with different lower-case letters are significantly different at $P<0.01$ 
according to seasons and that the ratio of allelochemicals particularly secreted in autumn and spring was higher than other seasons. While low doses of these allelochemicals can be tolerated with the roots and shoots of the plants, high concentrations can decrease or completely stop germination, growth and development of the plants. The findings of the present study showed that high concentrations of pine leaves extract had an inhibitory effect on growth and development in L. multiflorum, $F$. arundinacea and $A$. tenuis. These negative effects decreased with decrease in the concentration of the extract.

Ryegrass plants with small seeds are more sensitive to allelochemicals than ryegrass plants with large seeds (Coder 1999; Nektarios et al., 2005). Similarly, in the present study it was found that $L$. multiflorum, which is a rygrass species with large seeds, tolerated inhibitory effect of Scots pine leaf extracts to the highest extent. However, $A$. tenuis which has small seeds was exposed to allelochemicals particularly and at high concentrations germination and development almost stopped. Therefore, these species are recommended to be used more cautiously to prevent economic losses in creation of ryegrass areas. In addition, although factors take plant species ecological into account during the preparation of ryegrass mixtures, allelochemicals secreted by pine plants should also be considered and ryegrass species resistant to these chemicals should be preferred.

\section{References}

Agboola, D.A.: Dormancy and seed germination in some weeds and tropical wastelands. Nigerian J. Botany, 11, 79-87 (1998).

Baradat, Ph. and R. Yazdani : Genetic expression for mono-terpenes in clones of Pinus sylvestris grown on different sites. Scandinavian J. ForestRes., 3, 25-36 (1988).

Boz, Ö., M.N. Doğan and F. Albay: Olive processing wastes for weed control. Weed Res., 43, 439-443 (2003).

Bulut, Y. and M. Demir : The alleopathic effects of Scots pine (Pinus sylvestris $L$.) leaf extracts on turfgrass seed germination and seedling growth. Asian J. Chemistry, 19, 3169-3177 (2007).

Chaves, N. and J.C. Escudero : Allelopathic effects of Cistus ladanifer on seed germination. Functional Ecology, 11, 432-440 (1997).
Coder, K.D.:Allelopathy in trees. Arborist News, 8, 53-60 (1999).

Çamurköylü, N. and H. Demirkan : Allelopathy between weeds and crop and its importance in practice. Proceedings Book of $1^{\text {st }}$ Turkish Herbology Congress, Adana, Turkey, pp. 203-209 (1993).

Djurdjević, L., M. Mitrović, A. Dinić, P. Pavlović, S. Bojović, G. Gajić and O. Kostić : Allelopathic investigations of Quercus conferta and Quercus cerris domination in oak forest at Avala Mt. (Serbia). Proceedings Book of $4^{\text {th }}$ World Congress on Allelopathy, New South Wales, Australia, pp. 328-331 (2005).

Ercisli, S., A. Esitken, C. Turkkal and E. Orhan : The allelopathic effects of juglone and walnut leaf extracts on yield, growth, chemical and PNE compositions of strawberry cv. Fern., Plant Soil Environmental, 51, 283-287 (2005).

Jefferson, L.V. and M. Pennacchio : Allelopathic effects of foliage extracts from four Chenopodiaceae species on seed germination. J. Arid Environ., 55, 275-285 (2003).

Kainulainen, P. and J.K. Holopainen : Concentrations of secondary compounds in Scots pine needles at different stages of decomposition. Soil Biol. Biochem., 34, 37-42 (2002).

Kobayashi, K.: Factors affecting phytotoxic activity of allelochemicals in soil. Weed Biol. Manage., 4, 1-7 (2004).

Kocaçalışkan, I. and I. Terzi : Allelopathic effects of walnut leaf extracts and juglone on seed germination and seedling growth. J. Horticult. Sci. Biotechnol., 76, 436-440 (2001).

Muscolo, A. and M. Sidari : Seasonal fluctuations in soil phenolics of a coniferous forest: effects on seed germination of different coniferous species. Plant Soil, 284, 305-318 (2006).

Nektarios, P.E., G. Economou and C. Avgoulas : Allelopathic effects of Pinus halepensis needles on turfgrasses and biosensor plants. Allelopathy J., 40, 246-250 (2005).

Nerg, P., A. Kainulainen, M. Vuorinen, M. Hanso, K.J. Holopainen and T. Kurkela : Seasonal and geographical variation of terpenes, resinacids and total phenolics in nursery grown seedlings of Scots pine (Pinus sylvestris L.). New Phytologists, 128, 703-713 (1994).

Putnam, A.R. and J. DeFrank : Use of phytotoxic plant residues for selective weed control. Crop Protection, 2, 173-181 (1983).

Rice, E.L.:Allelopathy. $2^{\text {nd }}$ Edn., Academic Press, New York (1984).

Roshchina, V.V.: Effects of proteins, oxidants and antioxidants on germination of plant microspores. Allelopathy J., 23, $37-50$ (2009).

Roshchina, V.V., V.A. Yashin, A.V. Yashina and M.V. Goltyaev: Coloured allelochemicals in modelling of cell-cell allelopathic interactions. Allelopathy J., 28, 1-12 (2011). 